DOI: 10.2478 /ausp-2020-0029

\title{
On the Discourse of Online Sports News Headlines
}

\author{
Andrea PETERLICEAN \\ Department of Applied Linguistics \\ Sapientia Hungarian University of Transylvania (Cluj-Napoca, Romania) \\ Faculty of Technical and Human Sciences Târgu-Mureş, \\ andrea.peterlicean@ms.sapientia.ro \\ Elena-Cristina BERARIU \\ Dimitrie Cantemir University of Târgu-Mureş \\ cristina.berariu@gmail.com
}

\begin{abstract}
Sports discourse is one of the most common types of discourses today. It is regarded to be one of the types of media discourses which is supposed to display mainly features of description and commentary, with a unique, specialized vocabulary. This study focuses on sports news headlines published online. One of the objectives of the study is to establish some of the markers with respect to lexical choices, events, and formulation of content. Another objective is to see what ideologies these headlines may reveal.
\end{abstract}

Keywords: sports, discourse, online news, headlines, ideologies

\section{Introduction}

Whereas reality can be described in a variety of native tongues, English connects nations and their contributions to global progress by moving beyond borders and by creating a common environment in which communication can take place. With the increased diversification of knowledge branches, we may observe the intricate relationships that occur in the interpretation and description of reality in texts that are interrelated and build specific fields of expertise. This is why the interdiscursive feature is a key characteristic of the discourse of many specialized discourses, among which the discourse of sports news is to be listed.

Davis and Brewer (1997: 2) identify an important feature of online discourses, sharing the view that online writing is "writing that ... reads as if it were being spoken", suggesting that this could be one of the distinguishing traits of news reporting in online media. The role of social context cannot be understated in the 
case of news published online. Such an approach also appears to be in line with the perception that the "discourses ... are integral parts of communicative acts in some sociocultural situation" (van Dijk 1983). Furthermore, a special branch of discourse analysis, CDA, may be used to "understand ... a socially constructed, nuanced analysis of culture, identity and experience" (McGannon-Smith 2015).

News headlines are used by readers to obtain general information about what they are going to read. They are meant to attract readers' attention and generate interest in the content of the article. At times, there are meanings that come from beyond the linguistic expressions themselves. Some headlines may mislead by employing vocabulary that does not match the content of the article. Journalists and editors may prefer sensationalism to attract the public, such examples being common in all online media. Journalists are subjective: they may write headlines and news content with underlying ideologies, as highlighted, among others, by Hazard Owen (2017), who states: claiming news(papers) "are just being impartial observers, ... hurts trust in journalists". Lewis believes that when journalists "decide what to cover, they're making a subjective decision about what's important". ${ }^{1}$ Furthermore, Lombardi (2018) also points out that online headlines are "bearers of subjective truths and ideologies". ${ }^{2}$

The purpose of this study is to discover some of the linguistic and discursive devices and forms of rhetorical strategies that are used in online sports news headlines.

\section{Theoretical considerations}

Discourse analysis shows the relationship between the notions of ideology, discourse, and text. It is a meaningful way to consider the ways language is employed to represent different worldviews. The application of discourse analysis to news material offers meaningful insights and understanding of media perspectives, and it also focuses on how the meanings appear in media texts, while it may critically examine issues related to power and ideology.

Discourses are forms of our experiencing the world. The knowledge we have about the world plays an important role in how we understand the social world, people, and behaviours. This applies to all areas of life from politics to sports. To analyse discourses involves making assumptions about how power operates in society. Lukes (2005) believes that exercising power could be an individual's "supreme" wish. Then, Crystal (2004), Fowler et al. (1979), Kress and Hodge (1979), and Fairclough (1995) studied the facets of media language as well as some of its functions and recurrent patterns. Bell (1991) believes that the media use certain

1 https://medium.com/@ariamalula/why-its-okay-to-be-subjective-in-journalism-cab33be80a6d.

2 https://pdfs.semanticscholar.org/8e91/10d3c08bc4fd86705c9b9c96f5591edc4fb8.pdf. 
language features in a very specific way, and they play a role in affecting language in the wider society. Cotter (2003) writes that research on media has registered the presence of bias. Wodak and Busch (2004) suggest that the media produce and reproduce social meanings. All of the aforementioned contributions seem to agree with van Dijk's claim that ideologies "are acquired, spread, and reproduced by text and talk". ${ }^{3}$ Furthermore, ideologies are believed "to reside with varying degrees in different discourses” (Määttä 2014), representing "systems of social cognitions of groups" (van Dijk apud Freeden-Stears 2013). As far back as the beginning of the $20^{\text {th }}$ century, Adorno was concerned with the ideology of sport, arguing that sport produced dangerous, powerful, and social messages. This was later translated into the conception that sport is a cultural object which influences the development of individuals in capitalism, remaining among the powerful ideologies of the $20^{\text {th }}$ century (Mangan 2012).

In many countries, sports function as a major ideological and cultural force. We should not forget to mention the economic dimension of sporting phenomena. As with the other aspects of human activity, globalization has had an important contribution in the shaping of the world of sport and its discourses. Sports media carry information from one country to another, recording events to suit viewing times of international audiences and transport ideologies or philosophies by or through sport. While it may not be entirely accurate to use the term globalization when talking about sports discourse, there is a large body of evidence that suggests a focus on internationalization, a shift from national dimensions to broader ones. This is one of the reasons why we decided to focus on news headlines from countries such as the USA, Spain, or Italy.

A classification of discursive strategies that has been in use is the one which groups such according to their purpose: legitimation, credibility, and captation. ${ }^{4}$ The first group is believed to consist of those strategies through which an emitter in a communicative situation consolidates a certain legitimate position when there are doubts about the manner in which the receiver of the message perceives the sent message or when there is a discrepancy between the positions of authority of the emitter and the receiver. Credibility strategies presuppose various discursive attitudes (maintaining a neutral position, maintaining distance, or engaging into communicative acts), with the help of which the sender of a message imposes a reasoning method that will be accepted as it is. Captation strategies are based on polemic discursive attitudes of seduction or dramatizing, which help the sender of the message achieve an adhesion of the receiver to the proposed discursive project - a sharing of views, ideas, opinions, or emotions. Earlier studies also focused on similar modes of representation (Shapiro 1990). Focusing specifically on media discourse, Reisigl and Wodak (2009, 2016) write about nomination, predication,

3 http://www.discourses.org/OldArticles/Ideology\%20and\%20Discourse.pdf.

4 http://www.patrick-charaudeau.com/A-communicative-conception-of.html. 
argumentation, perspectivization, mitigation, and intensification and their purposes (discursive construction, characterization of social actors, persuading addressees, modifying forces of utterances, etc.). At this point, it would be useful to glance at the different types of context where discourses work: co-text, with its relevant thematic and syntactic features, lexical choices, collocations, connotations; co-discourse the relationships between texts and utterances, discourse representations; social factors and institutional features of special contexts of situation (style, place, time, occasion, ideologies, national and international identities). Montesano Montessori, Farrelly, and Mulderrig (2019) mention the topoi of authority and uncertainty as being frequently used in various types of discourse, while Dosena and Rosso (2016) highlight discursive strategies historically in Europe and the USA, looking at different genres and text types.

In recent years, we have seen a new approach to analysing metaphor and its placement into genre events. Steen (2008) proposes a three-dimensional model of metaphor - language, thought, and communication -, whereby we name and build up concepts and construct frames in which these concepts can be interpreted. According to Cameron (2008), metaphor makes difficult topics approachable. Langacker (2016) referred to metaphors and their presence in all fields of activity, emphasizing their lack of appropriateness, whereas Kövecses (2010) focused on the cultural specificity of metaphors. Molek-Kozakowska (2014) analysed the application of metaphors in news headlines (from the publication The Daily Mail) to prove how certain ideological representations can be forced onto the public through the use of figurative language. We attempt to find out what frequent conceptualization is like as a strategy in online sports headlines, alongside other strategies that we will develop in the following.

News as a form of mass communication has been divided into four categories of news discourse: print, online, radio, and TV (Bednarek-Caple 2018). News reporting as a type of media discourse has had the attention of scholars, who observed the influence of this kind of information dissemination. Bednarek and Caple (op. cit.) make a distinction between the functions and features of print and online news headlines, noticing similarities and differences, among which the most notable could be the purpose to attract readership and a similar format structure.

Newsworthiness has been one of the criteria in assessing pertinent news (Busa 2014), while van Dijk (1988) focused on the economic, social, and ideological categories of values. The latter also highlighted relevance structures in view of understanding the cognitive, social, and ideological production, processing, and use of news by readers. Similarly, according to van Dijk (op. cit), rhetorical structures are intertwined with the other structures of discourse. Furthermore, an essential objective could be the discovery of power relations and ideologies behind discourses, taking into consideration institutional as well as social and cultural contexts which underlie the production of news discourse. Richardson (2010) analyses discursive 
strategies and ideological standpoints, distinguishing between writers' strategies and readers' strategies. One such strategy appears to be that sensationalism will sell the news, a claim that was demonstrated to not be completely true for televised content (Vettehen-Cleemans 2017). Still, a large number of scientific studies have found that sensationalism attracts large audiences, especially when it comes to news with political content or broadcast news.

Modern media has created shifts in the scope, intensity, and effectiveness of the production and reception of messages. Online publications now offer synchronous and asynchronous modes of communication, making this medium an attractive place for provocation to thrive. Provocative narratives may be a result of the modification in media, and they appear to be present in many types of discourses. Steensen (2009) remarked that online journalism is now "marked by contradictions and inconsistencies".

In these uncertain times, where the dynamics of human activity are greatly impacted by restrictions imposed on social activities, the importance of online communication has increased. It has become an option, if not a necessity, for educational institutions, for accessing and sharing information perhaps more than before, when traditional resources were also available. In an internationalized context, cultural norms and values seem to converge on certain points, such as the ones relating to respect and honour, as well as in the reproduction of social power in discourse, as reflected in news headlines. The online dissemination of news continues with an apparent stronger need for positive self-representation.

Marking positions of authority and problematizing are phenomena that were studied by discourse analysts of the discourse on news. Evaluation of athletes, professional football players, and teams appear frequently in TV news and also in online media. The discourse of sport has been studied over time in dichotomies of public-private, professional-amateur, men-women, fantasy and television representations. Various genres of sports discourse have been addressed together with the way in which they shape activities at local and international level. In specific contexts and situations, they develop in conjunction with other discourses. In Romania, for example, there is a more or less humorous association of the discourses of sport and politics as Romanians believe they are knowledgeable and free to discuss such matters in public and in private, with varying degrees of authority in the matter. The structure of online news seems to try to cater for the tastes of this sort of public by dedicating special sections to opinion forums, with specific interests at the centre.

Authority in discourse has been studied in many areas, such as literature or the arts, questioning its source and impact (Everman 1988). In news, the power of the writer and the source appear to be related to the legitimacy of the quoted or mentioned characters. Authoritative speech is assumed to be produced by people with relevant experience: for instance, a carpenter will be more credible than a 
skincare blogger who would like to give advice on how to build a wooden cradle; by the same token, a football player who gives his opinions on football events should be seen as more reliable by supporters, fans, and readers of football news. News needs to be valid and verifiable, so knowledgeable sources will be quoted in order to ensure their validity.

Perceived credibility refers mostly to audience perceptions of news media, not to the credibility of journalists. Meyer (1988) refers to affiliation and believability as the main criteria in the measurement of the credibility factor. This may have to do with the previously mentioned criteria of reliability and validity.

\section{Methodology and analysis}

Language should be analysed as social practice (Fairclough), as behaviour (Van Dijk-Fauconnier-Turner), and as ideology (Wodak). Discourse analysis may offer insights into social problems (Van Dijk 1985) and could be meaningful for analysing different forms of interactions in various contexts, including messages transmitted by the media (Fairclough 2013). Discourse analysis is useful in the examination of the association between such messages and their social and cultural contexts (Van Dijk 2004), language content, themes, or issues discussed in the news (Gee 2014).

According to Van Dijk (1988), headlines are the items of information that readers are most likely to memorize from news. They give an insight into news writers' views of the world, which will probably influence readers' opinions of the depicted events.

The material was selected based on the perceived importance assigned to headlines as they are said to influence the reader's choice (to read or not to read the article whose headline they encounter). They are believed to appeal to readers and prompt them to engage and interact with texts and (their) socio-cultural context, thus being informative and persuasive.

This study is layered on two levels. Firstly, at the macro level, we apply Fairclough's CDA framework to reveal the relationship between news discourse and society. Secondly, at the micro level, we look at the discursive strategies employed online, namely: sensationalism, positive/negative (self-)representation, provocation, modality, evaluative language, topicalization, the use of authoritative remarks, problematizing, and assurance. These strategies have different communicative functions to help news writers achieve their aim of influencing and shaping readers' perceptions regarding sports events during the coronavirus pandemic. 


\section{Data collection}

Data for this paper were collected in the month of March, in the year 2020 from the websites: bbc.com, dailymail.co.uk, wwos.nine.com.au, reuters.com, euronews. com, foxnews.com, espn.com, skysports.com, gazzetta.it, marca.com, newsnow. co.uk, and cnn.com. The selected websites are available for public viewing all over the world for English-speaking communities, which is one of the reasons they were selected. Whereas in the case of politics or other domains the geographical location could be more relevant to people residing in a specific region, with sports in the global world the focus lies on the interests of readers, regardless of their position on the globe. Readers of sports news are said to be mainly people with an interest in general topics, who sometimes choose to access sports news (Shehu 2010). Headlines were selected taking into account frequency of access and number of readers as reported by ranker.com and similarweb.com. In addition to the access rate, news providers were chosen to cover a variety of contexts and geographical locations from Canada to Italy.

\subsection{Data analysis}

In the following, we are going to analyse the selected sports headlines. As we can see in Table 2, the news headlines selected display a number of features pertaining to lexical choice, events, and formulation of content. Many headlines contain some sort of reference to sports events likely to happen, events which have been scheduled but need to be re-scheduled. Most headlines contain abbreviations of organizations in charge of sports branch management, tournaments, etc. Sports people are mentioned by full name or simply by family name, with goals, options, and plans for the sporting season.

News writers are likely to employ discursive strategies, such as those mentioned in Table 2. They may employ strategies on various levels to achieve ideological aims. This is one of the reasons why we must look closely at the structures and strategies they use and the way they relate to the audience.

\subsection{News headlines, discourse, and society}

News discourse is considered to be complex, including communicative events and their social contexts, with attention directed towards text, participants, and opinions. Mardhyarini and Ariyanti (2016) suggest that news serve as ways "to express and deliver someone's ideas, show the power of a person or further persuade the ones who read that". ${ }^{5}$ The discourse of news is perceived to be a result of certain social and professional routines in institutional settings and a 
means to process information. Investigating text and context is meant to reveal the type of relationship(s) between the two. Headlines structure a view of the world, a categorization, which suggests a particular relation to the reader.

Some readers will choose to read local news, to be closer perhaps to their preoccupations, while others will access international news too. Headlines are a rich source of information about culture because they depend on the reader's recognition of the field, allusions and issues needed to access the content of the article. Thus, they rely on knowledge, representations, and models of reality that can be assigned meaning. References to the PM, Düsseldorf, or Ultimate Fighting Championship suppose an amount of social, political, and general knowledge and also help readers to situate themselves and the news within a national and international framework. The recognition of various types of lexical items, metaphorical expressions also relies on general linguistic knowledge. Wordplays are typical in headlines and are less likely to be found in the bodies of articles.

Sports news will make reference to specific historical events, like the Olympics, or to well-known figures of athletes, sports clubs, personalities' past and present, economic considerations, and so on. The use of linguistic and cultural forms helps readers to create a sense of community and identity. Sport is a universal component of each culture, so in the case of sports news a certain type of universal knowledge is accessed. Sport is a starting point for many conversations, so reading about sport is highly relevant in many countries.

Headlinese has established itself as a special means of communication among those employed by the media online and offline. Headlines have been known to meet the important requirement of fitting much information into as little space as possible. Headlines are believed to reach a wider audience since some readers will only glimpse at them fleetingly. The impact of headlines is likely to be strong because certain features are going to make them memorable and effective such as the use of puns, alliteration, emotive vocabulary, or special rhetorical devices.

Bell (1991) analyses the special syntax of English news headlines, while Mardh (1980) offers a list of headline features: the omission of articles, verbs, and auxiliaries; nominalization; the use of complex noun phrases; the use of short words, puns, and alliteration; the importance of word order; independent wh constructions not linked to a main clause. The following features have also been suggested: the lack of spatial and temporal markers; the use of the present tense of verbs; the suppression of declarative verbs; the disappearance of quotation marks, personal pronouns.

\subsection{Linguistic choices}

In online news, structures, patterns, and vocabulary seem to have common features with print news, at the same time showing a number of differences as well. Readership may also be different, with various intentions, and so could the aims of the writers/ 
editors be. Some of the tendencies regarding lexical items in news headlines were identified by Robescu (2008), while other researchers found ambiguity, vagueness, and strategic lexical choices to be characteristic of online news (Srivastava-Sahami 2009). Asmaradhani (2019) mentions nominalization and passivization, whereas Dykstra (2019) writes about expressiveness. All of these phenomena are to be analysed in a discourse that defines sport as means for achieving health and fitness, stress management, socialization, and relaxation (Doty 2006). Today, many believe that sport builds character.

In our examples, the language employed by headline writers comprises descriptive adjectives such as: eerie, supernatural, immobile, inexcusable or tough. What seems interesting is the use of antonyms, such as full or empty, in the same headline. Words with a negative connotation are also found in the headlines, but they refer more to restrictions and bans that are due to the ongoing health crisis: hiatus, it's like a horror movie. An event such as retirement from sporting activity is also to be encountered among the news items, with the well-established collocation announces retirement maintaining a neutral tone, leaving room for readers' subjective interpretations. Seven thousand miles, twelve yards and one small step is an intriguing construction, a creative interpretation and possible reformulation of the proverb a journey of a thousand mile begins with a single step. This, however, requires background knowledge of the history of Australian soccer, with moments of it mentioned in the narrative, including the occasion when a player had to shoot a penalty kick into Uruguay's goal post in 2006 with hopes to ensure his team's qualification to the World Cup. This moment meant victory for one side when the goal was scored and loss for the other, or the small step which meant the other team had fallen short of a great achievement.

Very fortunate events may happen in the pandemic. At least to some of us. As we can read in the headlines, idioms such as a dream come true or a golden day appear to confirm that sport builds strong characters, as the language used is not only positive but also contains specific reference to plans that can be fulfilled and to building strength of character and resilience: will come true, targets, defies, fears, and pledges are expressions that hint at character traits that aim for improvement, if not performance. The lexical field of sport is populated by terms that refer to branches of sport (tennis, rugby, baseball, gymnastics) as well as toponyms (Liverpool, Seattle, country names) or players' names (Sharapova, Rooney, Djokovic, Biles). The lexical field of health may be illustrated by the use of noun phrases, such as coronavirus outbreak, knee surgery, the verb heal, or the verbal collocation test positive. Nominalization is encountered in such examples as fairytale rise or immobile message, while infinitives can also be found: UK government to ban mass gatherings, Jude Bellingham to choose between four European clubs. These examples seem to show either future results of previously-made decisions or verbal promises or future events or plans. A different aim is illustrated by Wuhan 
football team leaving Spain to escape virus, the purpose of the Chinese football team being to steer clear of the virus. The negative will construction: Mariners won't play games in Seattle in March hints at a high degree of formality or an emphasis, while the implication is that the cancellation of games in Seattle is a certainty. Tokyo Olympics will go ahead appears to be a promise that has meanwhile been taken back, leaving us wondering whether the organizers' true intent when making this statement was to simply declare their intentions.

It may be for the sake of brevity that prepositions and participles are used: marathons called off, ...out after knee surgery, Spain drawn with Russia. Past participles appear in elliptical constructions that function as a stylistic device to indicate a certain degree of orality, as it appears that ellipsis is mostly common in spoken discourse (White 2013). Verb phrase ellipsis is believed to be frequent in news discourse, as pointed out by Hakobyan (2016) and Altarabin (2020).

A large number of acronyms and abbreviations in English are in common use as a means of simplifying and speeding up communication and have been demonstrated to cover an endless range of topics (Lwin 2012). MLB, UFC, and NT are used to convey a type of information in short, which is why THE BAT in Example 27 appears at first intriguing as it stands for the news writer's own system to rank/ select baseball hitters. It is generally recommended that certain types of words be capitalized in news headlines, for instance, verbs, and principle words. At the same time, using capital letters in online environments is sometimes regarded to be rude as it implies shouting/being shouted at.

\subsection{Content}

In the case of the 51 headlines selected for our study, a summary of the discursive strategies could look like the following:

Table 1. Frequency of discursive strategies in sports news headlines

\begin{tabular}{lc}
\hline Discursive strategy & Frequency \\
\hline Positive self-representation & 4 \\
\hline Topos of authority & 3 \\
\hline Establishment of assurance & 2 \\
\hline Authoritative remark & $\mathbf{1 7}$ \\
\hline Provocation & $\mathbf{1 2}$ \\
\hline Sensationalism & 2 \\
\hline Conceptualization/metaphorization & 2 \\
\hline
\end{tabular}

The results above indicate that the use of authoritative remarks and provocation seem to be the most frequent strategies employed, followed by positive selfrepresentation. 
Authoritative remarks are quotes that highlight the ideas being referred to in headlines and, at the same time, are an intertextual means of building news discourse. Using quotation helps render the impression of neutrality on behalf of the news writer, editor, or publication.

The writers tend to name organizations rather than individuals (e.g. European rugby club) to create a dichotomy of us versus them, which could cause heated debates. The choice of words is highly relevant and could function to hint at certain ideologies. The choice of figures of authority, such as a national team coach, Klopp, or Japan's Prime Minister, gives a certain weight and credibility to the news items.

Provocation in news headlines seems to suggest some sort of aggravation in order to illustrate actions that tend to stimulate discussion or trigger controversies.

Table 2. Sports news headlines in the month of March 2020

\begin{tabular}{|c|c|c|}
\hline Headline & Source & Discursive strategy \\
\hline $\begin{array}{l}\text { 1. Caster Semenya says she is 'supernatural' as she } \\
\text { targets Olympic } 200 \mathrm{~m}\end{array}$ & bbc.com & $\begin{array}{l}\text { Positive self- } \\
\text { representation }\end{array}$ \\
\hline $\begin{array}{l}\text { 2. Tokyo Olympics will go ahead, says Japan's PM } \\
\text { Shinzo Abe }\end{array}$ & bbc.com & $\begin{array}{l}\text { Modality } \\
\text { Topos of authority } \\
\text { Establishment of } \\
\text { assurance }\end{array}$ \\
\hline $\begin{array}{l}\text { 3. 'We're not stopping': UFC stages full fight card } \\
\text { in front of empty stadium in Brasilia despite } \\
\text { coronavirus epidemic as organisation's president } \\
\text { Dana White reveals he won't cancel shows }\end{array}$ & $\begin{array}{l}\text { https://www. } \\
\text { dailymail.co.uk/ }\end{array}$ & $\begin{array}{l}\text { Topos of authority } \\
\text { Establishment of } \\
\text { assurance }\end{array}$ \\
\hline $\begin{array}{l}\text { 4. 'A dream come true': Virgil van Dijk says his } \\
\text { fairytale rise through Holland's lower leagues will } \\
\text { make Premier League title success with Liverpool } \\
\text { even more special }\end{array}$ & $\begin{array}{l}\text { https://www. } \\
\text { dailymail.co.uk/ }\end{array}$ & $\begin{array}{l}\text { Positive self- } \\
\text { representation }\end{array}$ \\
\hline $\begin{array}{l}\text { 5. Jude Bellingham to 'choose between four } \\
\text { European clubs after Manchester United, Chelsea, } \\
\text { Borussia Dortmund and Bayern Munich all meet } \\
\text { Birmingham’s } £ 30 \mathrm{~m} \text { valuation’ } \\
\end{array}$ & $\begin{array}{l}\text { https://www. } \\
\text { dailymail.co.uk/ }\end{array}$ & Evaluative language \\
\hline $\begin{array}{l}\text { 6. Sergio Ramos works out on a treadmill, Neymar } \\
\text { watches Netflix and Lewis Hamilton goes rock- } \\
\text { climbing: What sports stars are up to as coronavirus } \\
\text { pandemic shuts down sporting world }\end{array}$ & $\begin{array}{l}\text { https://www. } \\
\text { dailymail.co.uk/ }\end{array}$ & $\begin{array}{l}\text { Positive self- } \\
\text { representation }\end{array}$ \\
\hline 7. London, Boston marathons called off & $\begin{array}{l}\text { https://wwos.nine. } \\
\text { com.au/news }\end{array}$ & Provocation \\
\hline 8. McLaren out of Aus GP after positive test & $\begin{array}{l}\text { https://wwos.nine. } \\
\text { com.au/news }\end{array}$ & Authoritative remark \\
\hline $\begin{array}{l}\text { 9. Reports: Pistons' Wood tests positive for } \\
\text { coronavirus }\end{array}$ & $\begin{array}{l}\text { https://www. /news/ } \\
\text { archive/sportsNews }\end{array}$ & Provocation \\
\hline $\begin{array}{l}\text { 10. Mixed martial arts: Oliveira wins in eerie silence } \\
\text { as UFC Brasilia defies coronavirus fears }\end{array}$ & $\begin{array}{l}\text { https://www.reuters. } \\
\text { com/news/archive/ } \\
\text { sportsNews }\end{array}$ & Provocation \\
\hline
\end{tabular}




\begin{tabular}{l}
\hline Headline \\
11. USA Gymnastics birthday tweet brings heated \\
Biles response \\
\hline $\begin{array}{l}\text { 12. NBA: Affected player Gobert pledges } \$ 500,000 \\
\text { to virus relief effort }\end{array}$ \\
13. Wuhan football team leaving Spain to escape \\
virus \\
14. Continued Georgian \& Japanese judoka success \\
at Düsseldorf
\end{tabular}

15. Racism in football: "The message being sent is devastating"

16. UEFA bans Manchester City from Champions League for two seasons

17. European rugby club signs player who said 'hell awaits' gay people

18. A golden day for Israel

19. Kid who got autograph from Utah Jazz player tests positive for coronavirus, but officials deny connection

\begin{tabular}{|c|c|c|}
\hline $\begin{array}{l}\text { 20. Portugal grouped with France in Nations League } \\
\text { title defense }\end{array}$ & $\begin{array}{l}\text { https://www. } \\
\text { foxnews.com/sports }\end{array}$ & Authoritative remark \\
\hline $\begin{array}{l}\text { 21. Pro Football Hall of Fame closing until March } \\
27 \text { due to coronavirus }\end{array}$ & $\begin{array}{l}\text { http://www.espn. } \\
\text { com/espn/latestnews }\end{array}$ & Authoritative remark \\
\hline $\begin{array}{l}\text { 22. Many team officials question start of NFL's } \\
\text { league year (March 15, 2020, 12:31 AM ET) }\end{array}$ & $\begin{array}{l}\mathrm{http} / / / \text { www.espn. } \\
\text { com/espn/latestnews }\end{array}$ & Problematizing \\
\hline $\begin{array}{l}\text { 23. NFL franchise tag tracker: Who's getting paid for } \\
\text { 2020, what's next (March 14, 2020, 4:41 PM ET) }\end{array}$ & $\begin{array}{l}\text { http://www.espn. } \\
\text { com/espn/latestnews }\end{array}$ & Problematizing \\
\hline $\begin{array}{l}24 \text { Vikings release CB Xavier Rhodes, NT Linval } \\
\text { Joseph to clear cap space (March 13, 2020, 9:39 PM } \\
\text { ET) }\end{array}$ & $\begin{array}{l}\text { http://www.espn. } \\
\text { com/espn/latestnews }\end{array}$ & Problematizing \\
\hline $\begin{array}{l}25 \text { MLB allowing players to go home after canceling } \\
\text { spring training (March 14, 2020, 3:16 AM ET) }\end{array}$ & $\begin{array}{l}\mathrm{http} / / \text { www.espn. } \\
\text { com/espn/latestnews }\end{array}$ & Authoritative remark \\
\hline $\begin{array}{l}\text { 26. Mariners won’t play games in Seattle in March } \\
\text { (March 13, 2020, 2:31 PM ET) }\end{array}$ & $\begin{array}{l}\mathrm{http}: / / \mathrm{www} . \text { espn. } \\
\text { com/espn/latestnews }\end{array}$ & Modality \\
\hline $\begin{array}{l}\text { 27. Fantasy baseball pitchers THE BAT identifies as } \\
\text { top values (March 12, 2020, 3:13 PM ET) }\end{array}$ & $\begin{array}{l}\text { http://www.espn. } \\
\text { com/espn/latestnews }\end{array}$ & Problematizing \\
\hline $\begin{array}{l}\text { 28. Adam Silver says NBA hiatus likely to last 'at } \\
\text { least' } 30 \text { days (March 13, 2020, 12:29 AM ET) }\end{array}$ & $\begin{array}{l}\mathrm{http}: / / \text { www.espn. } \\
\text { com/espn/latestnews }\end{array}$ & Authoritative remark \\
\hline $\begin{array}{l}\text { 29. Inside stories from the Chinese Basketball } \\
\text { Association's coronavirus-induced hiatus (March } \\
\text { 12, 2020, 1:46 PM ET) }\end{array}$ & $\begin{array}{l}\text { http://www.espn. } \\
\text { com/espn/latestnews }\end{array}$ & Provocation \\
\hline
\end{tabular}

\begin{tabular}{ll} 
Source & Discursive strategy \\
\hline $\begin{array}{l}\text { https://www.reuters. } \\
\text { com/news/archive/ } \\
\text { sportsNews }\end{array}$ & Authoritative remark \\
https://www.reuters. \\
$\begin{array}{l}\text { com/news/archive/ } \\
\text { sportsNews }\end{array}$
\end{tabular}
https://www.

euronews.com/news/ Authoritative remark sport

https://www.

euronews.com/news/ Conceptualization sport

Metaphorization

https://www. Provocation

https://www.

foxnews.com/sports

http://www.espn. com/espn/latestnews

http://www.espn. com/espn/latestnews

http://www.espn. (1) 洒 


\begin{tabular}{|c|c|c|}
\hline Headline & Source & Discursive strategy \\
\hline 30. Rooney: Footballers treated like guinea pigs & $\begin{array}{l}\text { https://www. } \\
\text { skysports.com/ } \\
\text { football/news }\end{array}$ & Authoritative remark \\
\hline 31. UK government to ban mass gatherings & $\begin{array}{l}\text { https://www. } \\
\text { skysports.com/ } \\
\text { football/news }\end{array}$ & Authoritative remark \\
\hline 32. Klopp's message to sports fans & $\begin{array}{l}\text { https://www. } \\
\text { skysports.com/ } \\
\text { football/news }\end{array}$ & Authoritative remark \\
\hline $\begin{array}{l}\text { 33. 'Language was inexcusable': US soccer chief } \\
\text { quits }\end{array}$ & $\begin{array}{l}\text { https://www. } \\
\text { skysports.com/ } \\
\text { football/news }\end{array}$ & Authoritative remark \\
\hline $\begin{array}{l}\text { 34. Real quarantined, Man City game off, La Liga } \\
\text { suspended }\end{array}$ & $\begin{array}{l}\text { https://www. } \\
\text { skysports.com/ } \\
\text { football/news }\end{array}$ & Provocation \\
\hline 35. Serie A clubs could lose $700 \mathrm{~m}$ & $\begin{array}{l}\text { https://www. } \\
\text { gazzetta.it }\end{array}$ & Modality \\
\hline 36. Barcelona look at Lazio's Luiz Felipe & $\begin{array}{l}\text { https://www. } \\
\text { gazzetta.it }\end{array}$ & $\begin{array}{l}\text { Positive self- } \\
\text { representation }\end{array}$ \\
\hline 37. Napoli organise singing flashmob & $\begin{array}{l}\text { https://www. } \\
\text { gazzetta.it }\end{array}$ & $\begin{array}{l}\text { Positive self- } \\
\text { representation }\end{array}$ \\
\hline 38. Immobile message to Dr Jessen & $\begin{array}{l}\text { https://www. } \\
\text { gazzetta.it }\end{array}$ & Authoritative remark \\
\hline 39. UEFA to change European competition format & $\begin{array}{l}\text { https://www. } \\
\text { gazzetta.it }\end{array}$ & Authoritative remark \\
\hline $\begin{array}{l}\text { 40. Papu: 'Bergamo is empty, it's like a horror } \\
\text { movie' }\end{array}$ & $\begin{array}{l}\text { https://www. } \\
\text { gazzetta.it }\end{array}$ & Authoritative remark \\
\hline 41. Real Madrid's injured players have time to heal & $\begin{array}{l}\text { https://www.marca. } \\
\text { com/en/ }\end{array}$ & Topicalization \\
\hline $\begin{array}{l}\text { 42. Official: FIA cancel Bahrain and Vietnam races } \\
\text { due to coronavirus outbreak }\end{array}$ & $\begin{array}{l}\text { (https://www.marca. } \\
\text { com/en/ }\end{array}$ & Topos of authority \\
\hline $\begin{array}{l}\text { 43. Real Madrid: How is Marcelo in trouble with the } \\
\text { Spanish government again }\end{array}$ & $\begin{array}{l}\text { https://www. } \\
\text { newsnow.co.uk/ }\end{array}$ & Sensationalism \\
\hline $\begin{array}{l}\text { 44. Inter Were Close To Signing Fabian Ruiz Two } \\
\text { Years Ago Before He Joined Napoli }\end{array}$ & $\begin{array}{l}\text { https://www. } \\
\text { newsnow.co.uk/ }\end{array}$ & Sensationalism \\
\hline $\begin{array}{l}\text { 45. Seven thousand miles, twelve yards and one } \\
\text { small step }\end{array}$ & $\begin{array}{l}\text { https://www. } \\
\text { newsnow.co.uk/ }\end{array}$ & $\begin{array}{l}\text { Conceptualization } \\
\text { Metaphorization }\end{array}$ \\
\hline $\begin{array}{l}\text { 46. Spain drawn with Russia and Ecuador in Davis } \\
\text { Cup }\end{array}$ & $\begin{array}{l}\text { https://www. } \\
\text { newsnow.co.uk/ }\end{array}$ & $\begin{array}{l}\text { Authoritative } \\
\text { language }\end{array}$ \\
\hline $\begin{array}{l}\text { 47. Maria Sharapova announces retirement from } \\
\text { tennis }\end{array}$ & $\begin{array}{l}\text { https://edition.cnn. } \\
\text { com/sport/tennis }\end{array}$ & Provocation \\
\hline $\begin{array}{l}\text { 48. Nick Kyrgios gives expletive-laden media } \\
\text { conference after being booed off court }\end{array}$ & $\begin{array}{l}\text { https://edition.cnn. } \\
\text { com/sport/tennis }\end{array}$ & Provocation \\
\hline $\begin{array}{l}\text { 49. Roger Federer out of French Open after knee } \\
\text { surgery }\end{array}$ & $\begin{array}{l}\text { https://edition.cnn. } \\
\text { com/sport/tennis }\end{array}$ & Provocation \\
\hline $\begin{array}{l}\text { 50. Novak Djokovic rallies to win eighth Australian } \\
\text { Open title }\end{array}$ & $\begin{array}{l}\text { https://edition.cnn. } \\
\text { com/sport/tennis }\end{array}$ & Provocation \\
\hline $\begin{array}{l}\text { 51. Djokovic says tough upbringing makes him } \\
\text { 'hungrier for success' }\end{array}$ & $\begin{array}{l}\text { https://edition.cnn. } \\
\text { com/sport/tennis }\end{array}$ & Authoritative remark \\
\hline
\end{tabular}




\section{Conclusions}

This paper analysed a number of headlines from some major news portals all over the world, focusing on sports news for English-speaking audiences. The discursive strategies used by news writers are revealed: lexical choices, intensification of the message using adjectives, maintaining a neutral stance using quotes, role labels, agencies, countries and events.

A multidisciplinary analysis of online news headlines may prove useful in the exploration of perspectives on the language of sports news. The headlines we selected were among the most accessed pieces of news in the period of the coronavirus pandemic of 2020. From the point of view of news headlines being examples of social practices, sports news headlines maintain institutional identities and bring to light evaluations as exemplified by the descriptive adjectives used. The examples we looked at seem to depict the news writers' representations of the sports world. Journalists/editors use direct quotes to give more credibility to the items of information the readers are likely to access in the articles while also employing figurative language to trigger varied mental associations in audiences across the globe. Linguistic features that other researchers reported to describe the language of news are to be encountered in the 51 headlines analysed: elliptical sentences, the use of present tenses, abbreviations and acronyms, metaphorical expressions. Participle constructions, adjectives belonging to related lexical fields (supernatural, fairytale), infinitives, and modals are also found in the selection of headlines that are neither too short nor too long, matching the writers' or editors' choices to promote their content. Figures of authority appear in the headlines as well as competition names and geographical locations where sports events are held. A number of social and cultural phenomena are also mentioned, such as racism and homosexuality, as well as behaviours that are deemed unacceptable (Kyrgios). There seems to be a tendency to portray such phenomena using negative connotation: “'hell awaits' gay people". As regards the underlying ideology, it may be argued that such language is used to describe oneself as superior and to present others as inferior. It may be possible that these representations are viewed differently depending on the social and cultural context where the news items are read. However, this could constitute the objective of future research.

Future research could continue along the same coordinates to analyse news in sports, including the analysis of sportscasting and comments on sports websites and forums. 


\section{References}

Altarabin, Mahmoud. 2020. On translating Arabic and English media texts: A coursebook for undergraduates. Cambridge Scholars Publishing.

Bednarek, Monica-Caple, Helen. 2018. News discourse. Bloomsbury Publishing.

Bell, Allan. 1991. The language of the news media. Blackwell.

Busa, M. Grazia. 2014. Introducing the language of the news: A student's guide. London: Routledge.

Dossena, Marina-Rosso, Stefano. 2016. Knowledge dissemination in the long nineteenth century: European and Transatlantic perspectives. Cambridge Scholars Publishing.

Everman, Welch D. 1988. Who says this? The authority of the author, the discourse and the reader. SIU Press.

Fairclough, Norman. 1995. Media discourse. London: Edward Arnold. 2013. Language and power ( $3^{\text {rd }}$ edition). London: Routledge.

Gee, James Paul. 2014. An introduction to discourse analysis: Theory and method ( $4^{\text {th }}$ edition). New York: Routledge.

Khalil, Esam N. 2000. Grounding in English and Arabic news discourse. AmsterdamPhiladelphia: John Benjamins Publishing Company.

Lukes, Steven. 2005. Power: A radical view (2 $2^{\text {nd }}$ edition). London: Palgrave.

Mangan, J. A. 2012 (ed.). Europe, sport, world. Shaping global societies (3). London: Routledge.

Mardh, Ingrid. 1980. Headlinese: On the grammar of English front page headlines. Malmo.

Määttä, Simo Kalervo. 2014. Discourse and ideology-Why do we need both? In: Callahan L. (ed.), Spanish and Portuguese across time, place, and borders. London: Palgrave Macmillan.

McGannon, Kerry R.-Smith, Brett. 2015. Centralizing culture in cultural sport psychology research: The potential of narrative inquiry and discursive psychology. Psychology of Sport and Exercise (17): 79-87.

Meyer, Philip. 1988. Defining and measuring credibility of newspapers: Developing an index. Journalism Quarterly 65: 567-574.

Reisigl, Martin-Wodak, Ruth. 2009. The discourse-historical approach. In: Wodak, R.-Meyer, M. (eds.), Methods of critical discourse analysis. (2 ${ }^{\text {nd }}$ edition). LondonThousand Oaks, CA-New Delhi: Sage. 87-121.

2016. The discourse-historical approach. In: Wodak, R.-Meyer, M. (eds.), Methods of critical discourse analysis ( $3^{\text {rd }}$ rev. edition). London-Thousand Oaks, CA-New Delhi: Sage. 23-61.

Montesano-Montessori, Nicolina-Farrelly, Michael-Mulderrig, Jane. 2019. Critical policy discourse analysis: Advances in critical policy studies. Edward Elgar Publishing. 
Richardson, John E. 2010. Language and journalism. New York: Routledge.

Srivastava, Ashok N.-Sahami, Mehran (eds.). 2009. Text mining: Classification, clustering and applications. Chapman and Hall.

Van Dijk, Teun A. 1988. News as discourse. Routledge: L. Erlbaum Associates. 2008. Discourse and power. Houndsmills: Palgrave.

2013. Ideology and discourse. In: Freeden, M.-Stears, Marc (eds.), The Oxford handbook of political ideologies. Oxford University Press.

\section{Web sources}

Alula, Ariam. 2018. Why it's okay to be subjective in journalism. https://medium. com/@ariamalula/why-its-okay-to-be-subjective-in-journalism-cab33be80a6d (downloaded on: 06. 25.2020).

Asmaradhani, Ahmad Idris. 2019. Implicit stances taken by ABC and BBC towards Indonesia presidential election: CDA perspectives. Journal of English Language Studies. http://jurnal.untirta.ac.id/index.php/JELS/article/download/6226/4417 (downloaded on: 06.02.2020).

Cameron, Lynne J. 2008. Metaphor and talk. In: Gibbs, R. W., Jr. (ed.), The Cambridge handbook of metaphor and thought. Cambridge University Press. 197-211. https://doi.org/10.1017/CBO9780511816802.013 (downloaded on: 06.01.2020).

Doty, Joseph. 2006. Sports builds character?! https://www.tandfonline.com/doi/ abs/10.2202/1940-1639.1529 (downloaded on: 06.28.2020).

Dykstra, Alan. 2019. Critical reading of online news commentary headlines: Stylistic and pragmatic aspects. Topics in linguistics. https://content.sciendo.com/view/ journals/topling/20/2/article-p90.xml (downloaded on: 06.20.2020).

Hakobyan, Gayane. 2016. Elliptical structures in newspaper discourse. https://www. researchgate.net/publication/303765151_Elliptical_Structures_in_Newspaper_ Discourse (downloaded on: 06.01.2020).

Kövecses, Zoltán. 2010. Metaphor and culture. Acta Universitatis Sapientiae, Philologica 2: 197-220. https://www.researchgate.net/publication/291103119_ Metaphor_and_Culture (downloaded on: 06.26.2020).

Langacker, Ronald W. 2016. Metaphor in linguistic thought and theory. Cognitive semantics. https://brill.com/view/journals/cose/2/1/article-p3_2.xml (downloaded on: 06.21.2020).

Lombardi, Daria. 2018. Critical discourse analysis of online news headlines: A case of the Stoneman Douglas High School shooting. https://pdfs.semanticscholar.org/8 e91/10d3c08bc4fd86705c9b9c96f5591edc4fb8.pdf (downloaded on: 06.28.2020).

Lwin, S. Marlar. 2012. Discourse patterns of acronyms and abbreviations used in Singapore news stories. https://www.researchgate.net/publication/260572108 Discourse_Patterns_of_Acronyms_and_Abbreviations_Used_in_Singapore_ News_Stories (downloaded on: 06.27.2020). 
Mardhyarini, Maqvira Rachma-Ariyanti, Lisetyo. 2016. Critical discourse analysis of the headline news in The Guardian and The Daily Telegraph. https://core. ac.uk/download/pdf/230651964.pdf (downloaded on: 06.30.2020).

Molek-Kozakowska, Katarzyna. 2014. Coercive metaphors in news headlines: A cognitive-pragmatic approach. Brno studies in English. https://digilib.phil. muni.cz/bitstream/handle/11222.digilib/131487/1_BrnoStudiesEnglish_4 0-2014-1_10.pdf?sequence=1 (downloaded on: 05.25.2020).

Robescu, Delia. 2008. Investigating the lexis of news reports. Professional communication and translation studies. https://sc.upt.ro/images/cwattachmen ts/113_7a925adb1da159bd7225eaf7fba4e8d4.pdf (downloaded on: 06.02.2020).

Shapiro, Michael J. 1990. Speaking the language of exile: Dissidence in international studies. International Studies Quarterly 34(3[Special Issue: Sept.]): 327-340. www.jstor.org (downloaded on: 05.30.2020).

Shehu, Jimoh (ed.). 2010. Gender, sport and development in Africa: Crosscultural perspectives on patterns of representations and marginalization. www. africanbookscolletive.com (downloaded on: 05.10.2020).

Steen, Gerard. 2008. The paradox of metaphor: Why we need a threedimensional model of metaphor. Metaphor and Symbol 23(4): 213-241. DOI: 10.1080/10926480802426753 (downloaded on: 03.30.2020).

Steensen, Steen. 2009. Online feature journalism. A clash of discourses. Journalism Practice (3)1. https://www.tandfonline.com (downloaded on: 05.30.2020).

Van Dijk, Teun A. 2004. From text grammar to critical discourse analysis: A brief academic autobiography. http://www.discourses.org (downloaded on: 10.03.2020).

Vettehen, Paul Hendriks-Kleemans, Mariska. 2017. Proving the obvious? What sensationalism contributes to the time spent on news video. https://journals. sagepub.com/doi/10.1177/1931243117739947 (downloaded on: 06.01.2020).

White, Jonathan R. 2013. Ellipsis as a marker of interaction in spoken discourse. Research in Language 2. http://webcache.googleusercontent.com/search? q=cache:ZGcgLiezqrgJ:cejsh.icm.edu.pl/cejsh/element/bwmeta1.element. hdl_11089_9677/c/v10015-012-0020-x.pdf+\&cd=16\&hl=ro\&ct=clnk\&gl=ro\&clien $\mathrm{t}=$ firefox-b-d (downloaded on: 06.03.2020).

*** http://www.discourses.org/OldArticles/Discourse\%20Analysis.Its \% 20 Development\%20and\%20Application.pdf 